\title{
Gempungan Tradition in Sundanese as Local Wisdom Learning Social Science Education in Primary School through Socio-Cultural Transformation
}

\author{
A. Andriani \\ Universitas Muhammadiyah Purwokerto \\ Ana.andriani@gmail.com
}

\begin{abstract}
Sundanese as an ethnic, have many customs that still continue to be used, especially in rural areas. There are positive values can be taken from the ancestral tradition of Sunda, both with regard to religious values, human values, moral values, social values, and others. This paper will raise one ethnic Sundanese tradition "gempungan" as the local wisdom to the study of Social Science Education at the elementary school in the socio-cultural transformation. This paper, using the literature review, interviews with the various parties involved, so that it will answer the questions: what is "gempungan"? How "gempungan" can be implemented? Anyone who is carrying out a "gempungan"? Can gempungan as a local wisdom held on Social Science education lessons in elementary school? What are the positive and negative impact of "gempungan"? Become the study in this paper. "Gempungan" Nowadays, it's different with gempungan performed by Sundanese elders. There is a cultural transformation in the activities of this gempungan, so give the understanding and meaning which is different from the previous one.
\end{abstract}

Keywords: Gempungan, Sundanese Customs, Social Science Education, elementary school, socio-cultural Transformation

\section{INTRODUCTION}

Culture is a way of life that developed and shared by a group of people. Culture can be passed down from generation to generation. It can be said also that culture is a holistic lifestyle that is complex, abstract and spacious, filled with the values of kindness. It is fitting that the noble values can be inherited and preserved by the next generation.

Sundanese culture is a culture Sundanese people who live in the area of Sunda precisely in the area of West Java. Duly maintained and preserved in everyday life by society. Where the values of goodness in Sundanese culture still able to maintain the identity and character of the Sundanese people. But what happens when this is, that young people tend not to understand Sunda when asked about his culture, hence the term "Pareumeun torch" (do not know the origin) is suitable for young people Sunda. Why is that? Because clearly visible, that many young people are not so interested Sunda again with Sundanese culture that is poorly understood and interpreted first applied in daily life. These conditions give rise to concerns of the elder citizens of Sunda, Sundanese culture and traditions that others will slowly become extinct.
Sunda tradition can be divided into two: First, the value contained in the Sunda tradition explicit knowledge (explicit knowledge), such as proverbs, tales, criticism, and ancient texts. Second, Sundanese traditional values derived from tacit knowledge (knowledge that is implied), this knowledge consists of mindset, attitudes, and wisdom Sundanese people in confronting and overcoming the problem of life. Sundanese culture should be preserved with priority inheritance of the two traditions of knowledge that express, or implied. But unfortunately this is still very poor, with a lack of knowledge about the development of Sundanese culture making it difficult for young people to still be able to "ngamumule" (preserve) culture.

One of them is the "Gempungan" (consultation) which seems to be something strange. Whereas gempungan Sundanese culture is one that has a high social value. Togetherness Sunda citizens in gempungan be a sign that the Sundanese people really appreciate the difference and still maintaining harmony. Life problems that always arise not make prolonged conflict. But it can be resolved through gempungan, Gempungan interpreted as meeting or "Bewara" in Sundanese society related to one thing and another. Although its implementation in each area is different. But his spirit remains the same which is to solve the problems that arise in the community with deliberation. Ideally gempungan carried out in the village to hold an existing problem to be taken way out. Can gempungan implemented in learning Social Science in elementary school? How gempungan in Sundanese tradition in the social and cultural transformation? Is there still relevant to the present condition of the Sundanese people? Or is outdated, because the values of tradition gempungan is not appropriate in this modern era? In this paper will be discussed related to the meaning of Gempungan as a tradition in Sundanese culture of learning in Social Studies in elementary school as a social and cultural transformation.

\section{DISCUSSION}

\section{A. Gempungan Tradition}

Melville J. Herskovits and Bronislaw Mallnowsi explained that everything contained in the society is determined by its culture. Why is that? because culture is always closely linked to the public. Likewise, the "gempungan" which is the culture of 
the Sundanese people who occupy most of the area of West Java. "Gempungan" is an activity that is performed as needed. The meaning of the word "gempungan" itself in Indonesian is: a meeting or assembly. The word "gempungan" is derived from the Sundanese also meaningful deliberations villagers. For most people, especially the Sunda itself that is already widely abandon traditional Sundanese. "Gempungan" words cannot be interpreted further. Whereas in the implementation gempungan laden noble values Sundanese culture. "Gempungan" can be a good communication tool between fellow citizens in conditions that tended to be selfish and individualistic.

"Gempungan" is an activity performed by villagers somewhere, can the village hall or in other places that have been approved by the community. Mediated by a set of villagers and elders, this gempungan implemented to resolve the problems that exist in society. Character heterogeneous citizens have a high potential for the emergence of various conflicts. Hopefully, through gempungan problems can be solved properly without conflict. Elders of the village and its presence became a figure which is expected to provide advice as well as fair and equitable solution in solving a problem. Not biased in making decisions and remain in a neutral position becomes a necessity to keep the environment remains conducive.

Kinds of public aspirations and various complaints can be submitted by the community to the village and elders. Of course many attitudes that must be held in conducting "gempungan" is. Appreciate and respect of fellow citizens become the first point that must be owned by all citizens of the community. Aiming for the benefit of society becomes the second point, as well as abide by the results gempungan become a necessity for all citizens who participate in the event.

\section{B. Customs Sunda}

Sunda initially not the name of an ethnic but a religion in the past that the meaning of the Sundanese words is as follows: "Su" means eternal or true, "Na" means fire, and "da" means large or grand, then Sunda meaning is "the great eternal fire (Sun)". Sunda religion actually have spread all over the world. Sunda and religion is the oldest religion of all religions from Islam, Christianity, (http://sundanese2013.blogspot.co.id/2013/03/tentangsunda.html)

Based on the book of Atma Jaya (1958: 8), Ptolemy mentions, there are three islands called Sunda located in east India. Based on that information experts then geographer Europe using Sundanese word for naming the area and a few islands in eastern India. Sunda words as well as said Rouffaer (1905: 16) is taken from the word Hindu culture as also says Sumatra, Madura, Bali, Sumbawa which all indicate the place. Sunda own word, probably derived from the root word "Sund" or the word "Suddha" in Sanskrit meaning: shining, bright, white (Williams, 1872: 1128, Eringa 1946: 289).

Sunda ethnic communities largely occupied areas of the island of Java, particularly areas in West Java. Sundanese people have a culture called Sunda Sundanese culture and traditions. Sundanese culture and tradition is something that grows and develops as well as living in a community environment Sunda. Known by the Sundanese culture that upholds the culture of manners. In general, the public character of Sunda was cheerful, welcoming (someah), smiling, gentle, and highly respect their parents. As if the character is a trademark Sunda citizens.

Sundanese culture is one of the oldest cultures in the archipelago. Sunda kingdom is often attributed as the ideal period Sundanese culture. There are several statements in Sundanese culture on the way to the primacy of life. Sunda ethos and character is cageur, bageur, singer, and clever, which can be defined with the word healthy, good, healthy (strong), and intelligent. Sundanese culture is also a culture that became hoarse wealth for Indonesia to be preserved. Sunda spiritual belief system, namely the "Sunda wiwitan" that teach harmonious living with nature.

Sundanese culture has certain characteristics that distinguish it from other regions. In general, the Sundanese people in the area known as the Sunda gentle community, religious, and spiritual. This is reflected in a slogan. "silihasih", "silihasah", and "silihasuh"; Love one another (priority interconnected nature of matter), mutually enhance or improve themselves, (through education and sharing knowledge) and protect each other (mutual maintain safety). Besides Sundanese also has a number of values such as modesty, humility towards others, respectful to elders, and love to the smaller ones. In the Sundanese culture magical balance is maintained by means of traditional ceremonies whereas social balance Sunda conduct mutual cooperation to maintain it.

http://id.wikipedia.org/wiki/budaya_Sunda

\section{Social Studies Education}

Social studies education as a subject at the school level, has two modes, namely as the integration of the whole concept of the essential disciplines of the social sciences for educational purposes (integrated social studies), and as teaching materials disciplinary simplified from each of the social science disciplines for the purpose of education (disciplinary social studies). For primary school, social studies education is basically a complete integration of the disciplines of the social sciences and other disciplines that are relevant for the purposes of education (citizenship education). As written by Barr et al. (1978) as follows:

"Social studies is an integration of social sciences and humanities for the purpose of instruction in citizenship education. We emphasize 'integratio' for social studies is the only field which deliberately attempts to draw upon, in an integrated fashion, the data of the social sciences and the insights of humanities. We emphasize 'citizenship' for social studies, despite the difference in orientation, outlook, purpose, and methode of teaching is almost universally perceived as preparation for citizenship in a democracy."

In the context of social studies teaching. On insights developed body of knowledge (body of knowledge). Every social science disciplines including: structural, fundamental idea, the main questions (mode of inquiry), the method used 
and the concept of each discipline so that learners can become social actors (social actor) intelligent (Bank, 1977). Social studies on the conceptual and practical level, by Barr et al (1977; 1978) are grouped into three pedagogical traditions, which is taught as a Social Studies (1) Citizenship transmission, (2) Social Science, (3) Reflective inquiry ". Which then gets the addition by Michaelis (1980), namely (4) Social studies as a social critism, (5) Social studies as personal development of the individual

Learning social studies in elementary school include natural features and socio-cultural diversity, utilization of natural resources (Natural Resources) in economic activity, ethnic diversity and historical heritage as well as social problems in the local environment, and others. Social studies education should be presented are varied to facilitate students in the learning process, so hopefully they can active learning, creative and independent. Learning social studies education is more emphasis on the ability of life (general life skills) and explore the values manners. In the process of teaching and learning are also teachers develop students interest in learning and improving skills of socializing between the knowledge of the condition of the people that are being developed in the community. Learning through social studies education will have an impact on the ability to think and reason of learners towards the better, so that the learning process can be meaningful.

Teachers are required to be able to develop a model of learning that can support the success of social studies learning so that students are able to think logically, systematically and critically. orientation on the objectives to be achieved; knowing and mastering the learning content of social studies education; many involve students in the learning process; students seek, find themselves, and learn to solve the problems that exist in society; and many use learning tools, learning resources and learning varied media. Expected to these factors, the quality can be further improved learning social studies.

\section{Social Cultural Transformation}

Edward B. Tylor explained that culture or civilization is a complex whole of knowledge, belief, art, morals, law, customs, and capabilities and habits acquired other in human beings as members of society. Culture is a humanizing process, it can be understood that in the cultural life changes, development, motivation. Likewise social cultural transformation. Changes in life becomes a very unusual, because life is dynamic.

The function of social human beings making human beings cannot be separated from the role of other communities. Life is the whole of the state of our self, the totality of what we do as human beings is the attitude, effort, and work should be done by everyone. Establishes an establishment in the order of social life that characterize human life as a social creature. Everything that exists in a society is determined by the culture of the community itself. Both the poor behavior and attitude determined cultural community. Each community has a culture that is continuously adhered and taught from generation to generation.
Adherence to culture in need as basic capital to be able to adapt and maintain viability. In this regard, in view of culture as values in biodiversity which is not a creation of its own culture of each individual to live and believe, everything that was obtained through the learning process. The process of learning is a way to pass values from generation to generation. Inheritance is known as socialization or enculturation process (the process of acculturation). There are three forms, namely the transformation of values that still fit to continue. For example, the values of honesty, sense of responsibility and others. Are less suitable, repaired, and that does not fit, be replaced. Examples culture of corruption and distorted is the target of transformative education.

Many found the negative impact caused by socio-cultural changes. it creates a void of meaning of socio-cultural change itself. As a result, each policy cannot solve the problem completely, and often lead to more serious social problems as a result of the policy.

Related to the cultural and social problems that is unique in every age. Socio-cultural changes into something common. The changes there with different logical consequences that accompany it. One example is, paternalistic pattern that must be institutionalized so that it can become a national potential and become a cultural value orientation ideal. As stated by Koentjaraningrat in his "human mentality Indonesia" This statement still realize that changes in Indonesian society concerning the cultural values (Orientation paternalistic).

Various approaches are implemented in order to progress related to changes in socio-cultural community. Among others are. The formal approach widely supported by the data and quantitative interpretation, but less attention to internal validity dimensional aspect of a social reality. Sectoral outlook is more emphasis on the aspect of social change, so that the topdown development more apparent than in the grassroots. As a consequence of development for the community and the community building.

\section{CONCLUSION}

Gempungan is an activity carried out by residents in a village to solve existing problems, and usually mediated by a set of tools and the village elders, the heterogeneous character of citizens have a high potential for the emergence of various conflicts. The expectation that the problem is not prolonged the main goal of gempungan. The role of the village and the elders of the community in activities gempungan must show a mature attitude is oriented to the common interest particular village should be able to mediate a fair and wise to become role models for their citizens. Not biased in making decisions and remain in a neutral position becomes a necessity to keep the environment remains conducive.

Gempungan is one of the activities contained in the Sunda tradition that has grown and live in their communities. Gempungan upholds the manners, in which a set of rules to be complied with and adhered to those who followed him. Mutual respect, and to prioritize the interests together into a necessity in its implementation. 
Modernization and globalization has affected the behavior of the Sundanese people, this might impact on the cultural traditions of the Sunda including gempungan. There has been a change in the meaning and implementation. Social and cultural transformation in Sundanese society raises new characters who also have an impact on people's behavior changes. However, it is expected Sundanese culture in traditional Sundanese community remain intact and sustainable without compromising the role of science and technology increasingly sophisticated as a global product.

Adherence to culture is maintained as the capital base to be able to adapt and maintain viability. Adherence to the culture also became evident that the young community Sunda respect and appreciate the great value of Sundanese culture as patrimony. Then it should be, young people appreciate and believe the Sundanese culture with the learning process. Inheritance is known as socialization or enculturation process (the process of acculturation). There are three forms, namely the transformation of values that still fits forwarded for example, the values of honesty, sense of responsibility and others, who are less fit, improved, and that does not fit, be replaced. Social and cultural transformation in Sundanese society can still be done by implementing the three forms above so Sundanese cultural tradition is maintained and sustainable.

Gempungan tradition as local wisdom can be applied in teaching social studies education, with the hope capable of engaging students so that they are active, creative, and independent during the study and can understand the positive values in the tradition gempungan. In addition, teachers of social studies education is also expected to equip students with the ability to develop knowledge and social science, in accordance with the development of society and science and technology. Social and cultural transformation in gempungan may be made to the primary school. With materials in accordance with the development of their age. So the purpose of social studies education is influenced by the ability of teachers in developing the media, sources, tools and strategies to learn and master the material that was developed based on the real life around the daily life of students can be achieved.

\section{REFERENCES}

[1] Pringgodigdo, ( 1973) Ensiklopedi Umum, Yogyakarta: Yayasan Kanisius

[2] Agus Salim, (2002) Perubahan Sosial, Sketsa Teori dan Refleksi Metodologi Kasus Indonesia, Yogyakarta: Tiara Wacana, 2002

[3] Soekanto, S. 1990 Sosiologi Suatru Pengantar. Jakarta: PT. RajaGrafindo Persada

[4] https://en.wikipedia.org/wiki/Main_Page

[5] http://kamuslengkap.com/kamus/sunda-indonesia/arti-kata/gempungan

[6] https://setiabudi208.wordpress.com/

[7] http://sundanese2013.blogspot.co.id/2013_03_01_archive.html

[8] http://id.wikipedia.org/wiki/budaya_Sunda

[9] http://duniabaca.com/definisi-budaya-pengertian-kebudayaan.html

[10] http://www.referensimakalah.com/2012/11/pengertian-transformasisosial.html

[11] http://karinarisaf.blogspot.co.id/2011/05/kebudayaan.html
[12] http://ferdisky.blogspot.co.id/2010/05/beda-tacit-knowledge-danexplicit.htm 